\title{
Evaluation of the results of coal jigging process
}

\author{
Agnieszka Surowiak ${ }^{1, *}$ \\ ${ }^{1}$ AGH - University of Science and Technology, Faculty of Mining and Geoengineering, Department of Environmental Engineering and \\ Mineral Processing, Cracow, Poland
}

\begin{abstract}
Quality of applied hard coal fuel to combustion processes influence significantly on process efficiency and effects of its influence on surrounding environment. It is particularly important issue in time of Clean Coal Technologies (CTW). The paper presents the analysis of hard coal beneficiation in a jig for getting an optimal recovery of useful fraction in concentrate (combustible matter) and not useful fraction (ash and sulfur). On the basis of industrial sampling of coal dust jig the density analysis of collected samples of concentrate and tailings was performed in laboratory conditions. In separated fractions of separation products the yields of products were calculated and the contents of ash and total sulfur were marked in them. On the basis of the results of density and chemical analyzes, separation products balance and appropriate calculations the Fuerstenau beneficiation curves were plotted which allowed to evaluate process and compare results of beneficiation of material containing various components. This is a different approach to evaluation of coal beneficiation effects, so far being used mainly for multi-component metals ores. Furthermore, the evaluation of separation preciseness on the basis of separation curves and factors was done and the statistical analysis of mutual correlations of analyzed parameters was done.
\end{abstract}

\section{Introduction}

So far, the results of hard coal beneficiation processes were presented usually by means of group of Henry upgrading curves on the basis of performed qualitative and quantitative analyzes and by performing appropriate calculations. This is the simplest method of graphical presentation of beneficiation results based on analysis of contents of certain component in feed, concentrate and tailings according to obtained density fractions. The basic Henry upgrading curve presents usually relation between yield and content of certain component in beneficiation products $\gamma=\mathrm{f}(\lambda)$. The case of ideal beneficiation is characterized on Henry curve by horizontal line presenting relation between fraction yield and content of useful component [1]. This basic information is often not sufficient because of the fact that separation preciseness determined by maximum accumulation of useful component in concentrate and possibly high amount of not useful ones in tailings becomes more and more important. Because of this there is a need of illustrate separation results in different way than the one preferred or generally accepted so far [13]. The tool making possible to evaluate efficiency of beneficiation of one product into useful component and simultaneous occurrence of not useful components of material in other product is Fuerstenau upgrading curve. Usually in technological practice this curve is being used to compare beneficiation results of metals ores as graphical relation presenting recoveries of analyzed components in concentrate and tailings. Fuerstenau curves are a good tool to compare selectivity of separation of two components occurring in material in purpose of determination of relation between recovery of one component in concentrate in function of second analyzed component in tailings $[1,3,4]$. The relation between selectivity of separation for ash content in coal was presented by Fuerstenau [1,2]. These curves are useful to analyze quality of produced clean coals if taking into consideration quality of concentrate for volatile matter and ash or sulfur content in tailings. Fuerstenau curve allows to determine optimal quality of concentrate on the basis of the point of biggest convexity $\mathrm{fF}$ or the point $\mathrm{F}$ being the point of intersection between the plot and ideal beneficiation curve. This point is obtained by plotting diagonal on Fuerstenau graph of coordinates $(0,0)$ and $(100,100)$. In spot of crossing diagonal with Fuerstenau curve the optimal beneficiation point $\mathrm{F}$ is obtained being related to the equality between combustible matter recovery in concentrate and residuals recovery in tailings . In case of coal residuals is sulfur or ash recovery in tailings. Additionally, the Fuerstenau curves are beneficial because they are constructed in the way ensuring elimination of the influence of feed changeability on separation results $[5,6]$.

\section{Industrial experiment}

The experimental investigation was based on sampling of industrial jig manufactured by Allmineral of working area being equal to $17 \mathrm{~m} 2$. This jig is installed in mineral processing plant of one of Polish hard coal mines. The experiments were performed by keeping constant number

\footnotetext{
* Corresponding author: asur@agh.edu.pl
} 
of pulsations which was equal to 26 cycles per minute. The capacity of the system, which is feed flow intensity was equal to $300 \mathrm{Mg} / \mathrm{h}$. Samples of concentrate and tailings from jig were collected by three changeable positions of additional water amounts in individual experiments. These amounts were equal to 35,50 and 70 $[\mathrm{m} 3 / \mathrm{h}]$, respectively. By such determined parameters, after stabilization of the process, the samples of separation products were collected from the jig in time of 3 minutes, each one at the same time. Then, the float and sink analysis in zinc chloride was performed for each collected sample of concentrate and tailings. The float and sink analysis was performed in solutions of zinc chloride of densities, respectively $1.30 ; 1.40 ; 1.50 ; 1.60 ; 1.70 ; 1.80$; $2.00 \mathrm{Mg} / \mathrm{m} 3$. In obtained density fractions the chemical analyzes for ash and total sulfur contents were performed.

\section{Elaboration of results}

The mass yields of size-density particle fractions obtained from all three experiments for jigging products were presented in Tables 1-3. Data characterizing feed parameters were obtained as a result of balance calculations [10].

Table 1. Mass yields of individual particle size fractions of jigging products, additional water $35\left[\mathrm{~m}^{3} / \mathrm{h}\right]$.

\begin{tabular}{|c|c|c|c|c|c|c|}
\hline \multirow[b]{2}{*}{$\begin{array}{c}\text { Density fraction } \\
{\left[\mathrm{Mg} / \mathrm{m}^{3}\right]}\end{array}$} & \multicolumn{3}{|c|}{ CONCENTRATE } & \multicolumn{2}{|c|}{ TAILINGS } & \multirow[b]{2}{*}{$\begin{array}{c}\text { Sulfur conten } \\
S_{\mathrm{t}}{ }^{\mathrm{a}}[\%]\end{array}$} \\
\hline & $\begin{array}{c}\text { Mass } \\
{[\mathrm{g}]}\end{array}$ & $\begin{array}{c}\text { Ash content } \\
\mathbf{A}_{\mathbf{t}}{ }^{\mathrm{a}}[\%]\end{array}$ & $\begin{array}{c}\text { Sulfur content } \\
S_{\mathbf{t}}{ }^{\mathrm{a}}[\%]\end{array}$ & $\begin{array}{c}\text { Mass } \\
{[\mathrm{g}]}\end{array}$ & $\begin{array}{c}\text { Ash content } \\
\mathbf{A}_{\mathbf{t}}{ }^{\mathrm{a}}[\%]\end{array}$ & \\
\hline$<1.3$ & 12960.0 & 3.63 & 0.77 & 4630.0 & 5.91 & 3.15 \\
\hline $1.3-1.4$ & 1375.0 & 9.29 & 2.80 & 5100.0 & 5.71 & 1.33 \\
\hline $1.4-1.5$ & 336.0 & 16.51 & 6.46 & 924.0 & 13.51 & 2.61 \\
\hline $1.5-1.6$ & 265.0 & 28.91 & 6.02 & 695.0 & 23.75 & 3.84 \\
\hline $1.6-1.7$ & 265.0 & 35.54 & 7.66 & 744.0 & 32.84 & 6.07 \\
\hline $1.7-1.8$ & 221.0 & 31.00 & 16.30 & 1010.0 & 39.55 & 6.68 \\
\hline $1.8-2.0$ & 367.0 & 42.54 & 14.29 & 3970.0 & 33.48 & 5.59 \\
\hline$>2.0$ & 366.0 & 57.70 & 17.23 & 20034.0 & 43.79 & 7.47 \\
\hline
\end{tabular}

Table 2. Mass yields of individual particle size fractions of jigging products, additional water $50\left[\mathrm{~m}^{3} / \mathrm{h}\right]$.

\begin{tabular}{|c|c|c|c|c|c|c|}
\hline \multirow{2}{*}{$\begin{array}{c}\text { Density fraction } \\
{\left[\mathrm{Mg} / \mathrm{m}^{3}\right]}\end{array}$} & \multicolumn{3}{|c|}{ CONCENTRATE } & \multicolumn{2}{|c|}{ TAILINGS } & \multirow[b]{2}{*}{$\begin{array}{c}\text { Sulfur content } \\
\mathrm{St}_{\mathrm{t}}{ }^{\mathrm{a}}[\%]\end{array}$} \\
\hline & $\begin{array}{c}\text { Mass } \\
{[\mathrm{g}]}\end{array}$ & $\begin{array}{c}\text { Ash content } \\
\mathbf{A t}^{\mathrm{a}}[\%]\end{array}$ & $\begin{array}{c}\text { Sulfur content } \\
S_{t}{ }^{a}[\%]\end{array}$ & $\begin{array}{c}\text { Mass } \\
{[\mathrm{g}]}\end{array}$ & $\begin{array}{c}\text { Ash content } \\
\mathbf{A t}^{\mathrm{a}}[\%]\end{array}$ & \\
\hline$<1.3$ & 12918.0 & 2.97 & 0.69 & 3822.0 & 3.62 & 1.04 \\
\hline $1.3-1.4$ & 2123.0 & 8.09 & 1.94 & 2962.0 & 5.47 & 1.12 \\
\hline $1.4-1.5$ & 284.0 & 18.71 & 4.52 & 1852.0 & 8.21 & 1.51 \\
\hline $1.5-1.6$ & 160.0 & 28.89 & 8.34 & 926.0 & 15.33 & 2.37 \\
\hline $1.6-1.7$ & 355.0 & 35.02 & 10.04 & 1084.0 & 27.08 & 3.69 \\
\hline $1.7-1.8$ & 565.0 & 42.98 & 15.36 & 1930.0 & 29.81 & 4.28 \\
\hline $1.8-2.0$ & 2812.0 & 56.43 & 22.97 & 8352.0 & 43.58 & 5.90 \\
\hline$>2.0$ & 17091.0 & 68.42 & 5.19 & 31410.0 & 67.47 & 12.84 \\
\hline
\end{tabular}

Table 3. Mass yields of individual particle size fractions of jigging products, additional water $70\left[\mathrm{~m}^{3} / \mathrm{h}\right]$.

\begin{tabular}{|c|c|c|c|c|c|c|}
\hline \multirow{2}{*}{$\begin{array}{c}\text { Density fraction } \\
{\left[\mathrm{Mg} / \mathrm{m}^{3}\right]}\end{array}$} & \multicolumn{3}{|c|}{ CONCENTRATE } & \multicolumn{2}{|c|}{ TAILINGS } & \multirow[b]{2}{*}{$\begin{array}{c}\text { Sulfur content } \\
\mathbf{S}_{\mathbf{t}}{ }^{\mathrm{a}}[\%]\end{array}$} \\
\hline & $\begin{array}{c}\text { Mass } \\
{[\mathrm{g}]}\end{array}$ & $\begin{array}{c}\text { Ash content } \\
\mathbf{A}_{\mathbf{t}}{ }^{\mathrm{a}}[\%]\end{array}$ & $\begin{array}{c}\text { Sulfur content } \\
\mathbf{S}_{\mathbf{t}}{ }^{\mathrm{a}}[\%]\end{array}$ & $\begin{array}{c}\text { Mass } \\
{[\mathrm{g}]}\end{array}$ & $\begin{array}{c}\text { Ash content } \\
\mathbf{A}_{\mathbf{t}} \mathbf{a}^{\mathrm{a}}[\%]\end{array}$ & \\
\hline$<1.3$ & 13945.0 & 3.49 & 0.73 & 1499.0 & 3.65 & 1.00 \\
\hline $1.3-1.4$ & 2817.0 & 8.83 & 1.38 & 3042.0 & 6.06 & 1.28 \\
\hline $1.4-1.5$ & 419.0 & 20.24 & 2.58 & 1920.0 & 8.32 & 1.49 \\
\hline $1.5-1.6$ & 108.0 & 36.35 & 4.53 & 1431.0 & 10.73 & 1.71 \\
\hline $1.6-1.7$ & 84.0 & 45.02 & 6.49 & 1448.0 & 14.03 & 2.24 \\
\hline $1.7-1.8$ & 46.0 & 52.98 & 10.26 & 1289.0 & 26.49 & 3.33 \\
\hline $1.8-2.0$ & 59.0 & 65.23 & 18.97 & 4062.0 & 40.91 & 6.91 \\
\hline$>2.0$ & 13.0 & 72.38 & 35.16 & 36123.0 & 69.33 & 12.22 \\
\hline
\end{tabular}

\subsection{Analysis of coal dusts beneficiation}

For the purposes of this work the Fuerstenau upgrading curves were used as a tool to evaluate effects of coal dusts separation process conducted in a jig. On the basis of data presented in Tables 1, 2 and 3 the balances of components were elaborated and the feed parameters were calculated in this way. According to the rules presented by Stepinski [10] the coordinates were calculated and the upgrading curves were plotted in coordinates system: combustible matter recovery in concentrate - ash recovery in tailings and combustible matter recovery in concentrate - sulfur recovery in tailings, which were positioned in Table 4 for all performed experiments. The combustible matter 
recovery in concentrate was calculated according to the formula:

$$
\varepsilon=\gamma_{k} \frac{100-\vartheta_{A}}{100-\alpha_{A}}
$$

where: $\gamma_{k}$ - concentrate yield, $\vartheta_{A}$ - ash content in concentrate, $\alpha_{A}$ - ash content in feed.

Ash recovery in tailings was calculated as:

$$
\varepsilon^{\prime}=\gamma_{0} \frac{\beta_{A}}{\alpha_{A}}
$$

Sulfur recovery in tailings was calculated as:

$$
\varepsilon^{\prime \prime}=\gamma_{0} \frac{\beta_{S}}{\alpha_{S}}
$$

where: $\gamma_{o}$ - tailings yield, $\beta_{A}$ - ash content in tailings, $\beta_{S}$ - sulfur content in tailings, $\alpha_{A}$ - ash content in feed, $\alpha_{S}$ -

\begin{tabular}{|c|c|c|c|c|c|c|c|c|c|}
\hline \multirow{3}{*}{$\begin{array}{l}\text { Density } \\
\text { fraction } \\
{\left[\mathrm{Mg} / \mathrm{m}^{3}\right]}\end{array}$} & \multirow{2}{*}{\multicolumn{3}{|c|}{$\begin{array}{c}\begin{array}{c}\text { Combustible matter recovery in } \\
\text { concentrate } \Sigma \varepsilon[\%]\end{array} \\
\begin{array}{c}\text { Amount of additional water } \\
{\left[\mathrm{m}^{3} / \mathrm{h}\right]}\end{array}\end{array}$}} & \multirow{2}{*}{\multicolumn{3}{|c|}{$\begin{array}{c}\text { Ash recovery in tailings } \Sigma \varepsilon^{\prime} \\
\begin{array}{c}\text { Amount of additional water } \\
{\left[\mathrm{m}^{3} / \mathrm{h}\right]}\end{array}\end{array}$}} & \multirow{2}{*}{\multicolumn{3}{|c|}{$\begin{array}{c}\text { Sulfur recovery in tailings } \Sigma \varepsilon^{\prime \prime} \\
\begin{array}{c}\text { Amount of additional water } \\
{\left[\mathrm{m}^{3} / \mathrm{h}\right]}\end{array}\end{array}$}} \\
\hline & & & & & & & & & \\
\hline & 35 & 50 & 70 & 35 & 50 & 70 & 35 & 50 & 70 \\
\hline$<1.3$ & 50.74 & 51.09 & 32.05 & 100.00 & 100.00 & 100.00 & 100.00 & 100.00 & 100.00 \\
\hline $1.3-1.4$ & 70.76 & 71.23 & 44.63 & 91.38 & 97.45 & 97.56 & 58.76 & 96.03 & 97.39 \\
\hline $1.4-1.5$ & 75.58 & 76.06 & 47.64 & 89.16 & 96.91 & 96.79 & 51.84 & 95.21 & 96.70 \\
\hline $1.5-1.6$ & 78.71 & 79.20 & 49.61 & 88.94 & 96.85 & 96.68 & 51.15 & 95.12 & 96.61 \\
\hline $1.6-1.7$ & 81.94 & 82.44 & 51.63 & 88.77 & 96.81 & 96.62 & 50.68 & 95.07 & 96.56 \\
\hline $1.7-1.8$ & 85.71 & 86.21 & 53.97 & 88.52 & 96.75 & 96.53 & 49.95 & 95.00 & 96.50 \\
\hline $1.8-2.0$ & 98.34 & 98.43 & 60.93 & 88.14 & 96.60 & 96.16 & 47.62 & 94.80 & 96.21 \\
\hline$>2.0$ & 100.00 & 100.00 & 100.00 & 85.07 & 93.39 & 85.29 & 7.99 & 90.26 & 87.83 \\
\hline
\end{tabular}
sulfur content in feed.

Table 4. Calculated coordinates to plot Fuerstenau curves.

The Fuerstenau upgrading curves were presented on Figs 1-3 in system: combustible matter recovery in concentrate - ash recovery in tailings on curves a) and combustible matter recovery in concentrate - sulfur recovery in tailings on curves b) for various amounts of additional water directed to the jig. By means of these Figures the technologically optimal beneficiation point $F$ was determined for each case. The best effects of separation of combustible substance in concentrate and ash in tailings were obtained in experiment with amount of additional water being equal to $50[\mathrm{~m} 3 / \mathrm{h}]$ in which

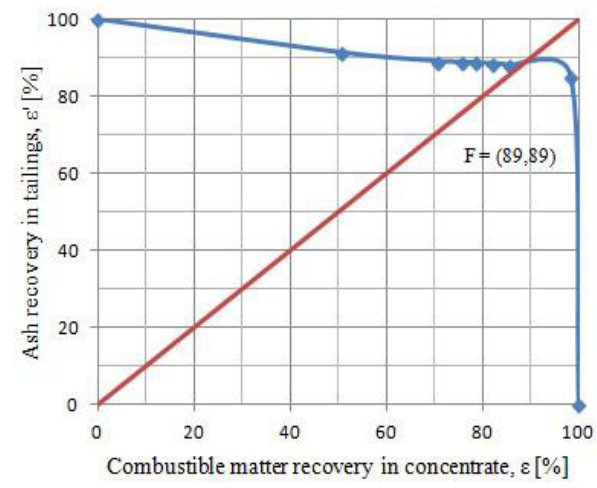

a)

Fig. 1. Fuerstenau's curves in functions of ash and sulfur recoveries. Ilość wody podsitowej $35\left[\mathrm{~m}^{3} / \mathrm{h}\right]$, a) Fuerstenau's curve in function of ash recovery in tailings, b) Fuerstenau's curve in function of sulfur recovery in tailings. optimal recovery of combustible matter in concentrate being equal to ash recovery in tailings $=98$. Furthermore, for this case the best effect of combustible matter and sulfur separation was obtained, which recovery was equal to 95. The worst result of separation of ash and combustible matter being equal to 68 was obtained in experiment with amount of additional water being equal to $70[\mathrm{~m} 3 / \mathrm{h}]$. The worst result of separation of sulfur and combustible matter in tailings being equal to only 56 was obtained for the experiment where the amount of additional water was equal to $35[\mathrm{~m} 3 / \mathrm{h}]$.$] .$

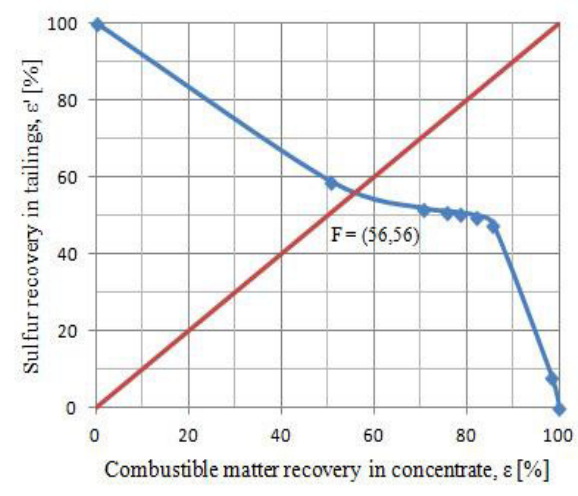

b) 
a)

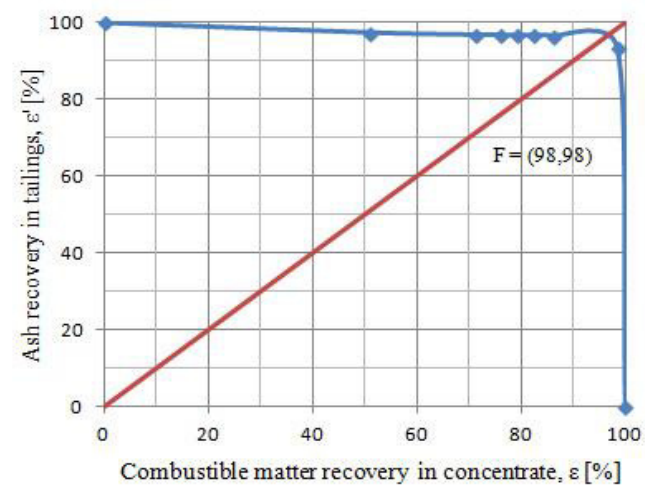

Fig. 2. Fuerstenau's curves in functions of ash and sulfur recoveries. Ilość wody podsitowej $50\left[\mathrm{~m}^{3} / \mathrm{h}\right]$, a) Fuerstenau's curve in function of ash recovery in tailings, b) Fuerstenau's curve in function of sulfur recovery in tailings.

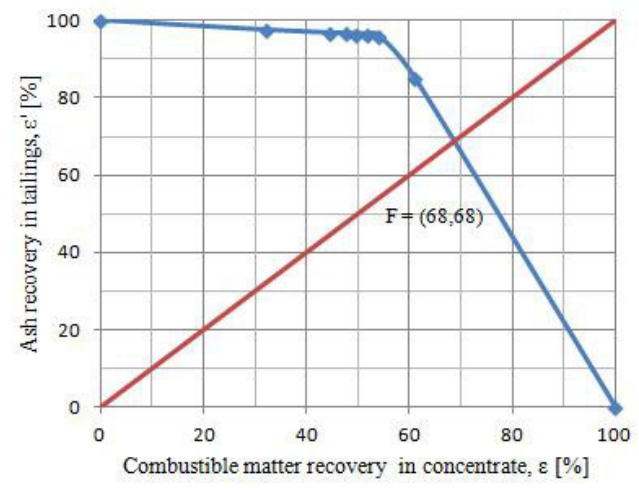

a)

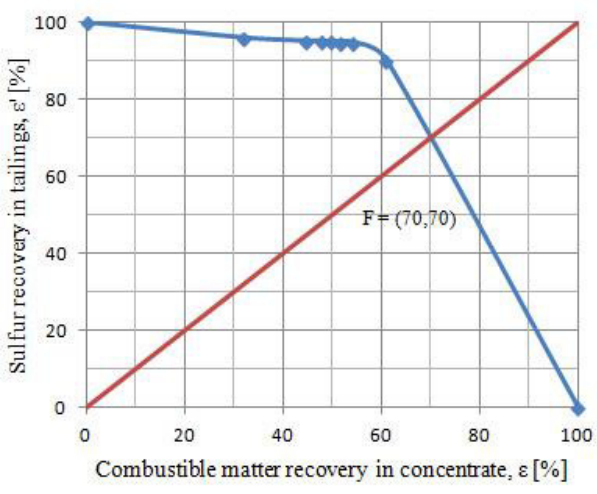

b)

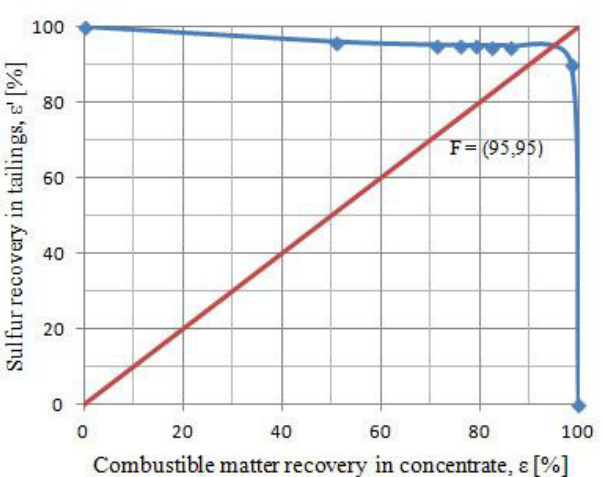

Fig. 3. Fuerstenau's curves in functions of ash and sulfur recoveries. Ilość wody podsitowej $70\left[\mathrm{~m}^{3} / \mathrm{h}\right]$, a) Fuerstenau's curve in function of ash recovery in tailings, b) Fuerstenau's curve in function of sulfur recovery in tailings.

\subsection{Statistical analysis of obtained results}

In purpose of verification of mutual relations between variables for obtained results presented in Tables 1-4 the basic statistical evaluation was done for parameters of performed experiments and obtained results of jigging. The linear correlation coefficients matrices were determined for all investigated factors. The obtained results were positioned in Tables 5-7. Analyzing the mutual correlations in individual experiments is possible to notice that the strongest correlated variables are combustible matter recoveries with density and ash contents in concentrate. It is particularly visible in first and second experiment, with amount of additional water being equal 35 and $50[\mathrm{~m} 3 / \mathrm{h}]$. Furthermore, the ash recovery in tailings is highly correlated with combustible matter and sulfur recoveries, what is particularly visible in second experiment. That is why the separation of these components was the most efficient by the amount of additional water being equal to $50[\mathrm{~m} 3 / \mathrm{h}]$. The statistical analysis indicated that in experiment with the amount of additional water being equal to $70[\mathrm{~m} 3 / \mathrm{h}]$ all recoveries are highly correlated as well there are significant relations between them and sulfur contents in concentrate and tailings. As a result worse beneficiation effects were obtained than in second experiment with amount of additional water being equal to $50[\mathrm{~m} 3 / \mathrm{h}]$.

Table 5. Correlation coefficients for variables from experiment with amount of additional water being equal to $35\left[\mathrm{~m}^{3} / \mathrm{h}\right]$.

\begin{tabular}{|c|c|c|c|c|c|c|c|c|c|c|}
\hline \multirow[b]{2}{*}{$\mathbf{T}$} & \multicolumn{10}{|c|}{ Determined correlation coefficients are significant with $p<0.5000$} \\
\hline & Mean & $\begin{array}{c}\text { Std } \\
\text { deviation }\end{array}$ & $\mathbf{P}$ & Ac & $\mathbf{A}_{\mathbf{T}}$ & $\varepsilon$ & $\varepsilon '$ & $\varepsilon "$ & $\mathbf{S}_{\mathbf{C}}$ & $\mathbf{S}_{\mathbf{T}}$ \\
\hline $\mathbf{P}$ & 1.619 & 0.253 & 1.0000 & 0.9686 & 0.9413 & 0.9393 & -0.7668 & -0.8028 & 0.9457 & 0.8874 \\
\hline $\mathbf{A}_{\mathbf{C}}$ & 28.140 & 17.872 & 0.9686 & 1.0000 & 0.9299 & 0.9279 & -0.8148 & -0.8638 & 0.8666 & 0.8670 \\
\hline $\mathbf{A}_{\mathbf{T}}$ & 24.817 & 14.966 & 0.9413 & 0.9299 & 1.0000 & 0.8603 & -0.7517 & -0.7490 & 0.9255 & 0.9607 \\
\hline$\varepsilon$ & 80.222 & 15.743 & 0.9393 & 0.9279 & 0.8603 & 1.0000 & -0.9163 & -0.8922 & 0.8932 & 0.7214 \\
\hline$\varepsilon$, & 89.9975 & 4.3948 & -0.7668 & -0.8148 & -0.7517 & -0.9163 & 1.0000 & 0.9431 & -0.7564 & -0.5597 \\
\hline$\varepsilon^{\prime \prime}$ & 52.2487 & 24.8192 & -0.8028 & -0.8638 & -0.7490 & -0.8922 & 0.9431 & 1.0000 & -0.7682 & -0.6029 \\
\hline $\mathbf{S}_{\mathbf{C}}$ & 8.9412 & 6.2367 & 0.9457 & 0.8666 & 0.9255 & 0.8932 & -0.7564 & -0.7682 & 1.0000 & 0.8603 \\
\hline $\mathbf{S}_{\mathbf{T}}$ & 4.5925 & 2.1724 & 0.8874 & 0.8670 & 0.9607 & 0.7214 & -0.5597 & -0.6029 & 0.8603 & 1.0000 \\
\hline
\end{tabular}


Table 6. Correlation coefficients for variables from experiment with amount of additional water being equal to $50\left[\mathrm{~m}^{3} / \mathrm{h}\right]$.

\begin{tabular}{|c|c|c|c|c|c|c|c|c|c|c|}
\hline \multirow[b]{2}{*}{$\mathbf{T}$} & \multicolumn{10}{|c|}{ Determined correlation coefficients are significant with $\mathrm{p}<\mathbf{0 . 5 0 0 0}$} \\
\hline & Mean & $\begin{array}{c}\text { Std } \\
\text { deviation }\end{array}$ & $\mathbf{P}$ & $\mathbf{A}_{\mathbf{C}}$ & $\mathbf{A}_{\mathbf{T}}$ & $\varepsilon$ & $\varepsilon$, & $\varepsilon "$ & $\mathbf{S}_{\mathbf{C}}$ & $\mathbf{S}_{\mathbf{T}}$ \\
\hline $\mathbf{P}$ & 1.619 & 0.253 & 1.0000 & 0.9978 & 0.9649 & 0.9372 & -0.8139 & -0.8096 & 0.6566 & 0.8879 \\
\hline $\mathbf{A}_{\mathbf{C}}$ & 32.688 & 22.834 & 0.9978 & 1.0000 & 0.9666 & 0.9424 & -0.8402 & -0.8361 & 0.6283 & 0.8975 \\
\hline $\mathbf{A}_{\mathbf{T}}$ & 25.071 & 22.007 & 0.9649 & 0.9666 & 1.0000 & 0.8678 & -0.8439 & -0.8315 & 0.4593 & 0.9735 \\
\hline$\varepsilon$ & 80.582 & 15.631 & 0.9372 & 0.9424 & 0.8678 & 1.0000 & -0.8753 & -0.8821 & 0.6681 & 0.7786 \\
\hline$\varepsilon '$ & 96.845 & 1.786 & -0.8139 & -0.8402 & -0.8439 & -0.8753 & 1.0000 & 0.9992 & -0.2324 & -0.8617 \\
\hline$\varepsilon^{\prime \prime}$ & 95.186 & 2.628 & -0.8096 & -0.8361 & -0.8315 & -0.8821 & 0.9992 & 1.0000 & -0.2474 & -0.8440 \\
\hline $\mathbf{S}_{\mathbf{C}}$ & 8.631 & 7.459 & 0.6566 & 0.6283 & 0.4593 & 0.6681 & -0.2324 & -0.2474 & 1.0000 & 0.2526 \\
\hline $\mathbf{S}_{\mathbf{T}}$ & 4.093 & 3.923 & 0.8879 & 0.8975 & 0.9735 & 0.7786 & -0.8617 & -0.8440 & 0.2526 & 1.0000 \\
\hline
\end{tabular}

Table 7. Correlation coefficients for variables from experiment with amount of additional water being equal to $70\left[\mathrm{~m}^{3} / \mathrm{h}\right]$.

\begin{tabular}{|c|c|c|c|c|c|c|c|c|c|c|}
\hline \multirow[b]{2}{*}{$\mathbf{T}$} & \multicolumn{10}{|c|}{ Determined correlation coefficients are significant with $\mathbf{p}<\mathbf{0 . 5 0 0 0}$} \\
\hline & Mean & $\begin{array}{c}\text { Std } \\
\text { deviation }\end{array}$ & $\mathbf{P}$ & $\mathbf{A}_{\mathbf{C}}$ & $\mathbf{A}_{\mathbf{T}}$ & $\varepsilon$ & $\varepsilon ’$ & $\varepsilon ’$ & $\mathbf{S}_{\mathbf{C}}$ & $\mathbf{S}_{\mathbf{T}}$ \\
\hline $\mathbf{P}$ & 1.619 & 0.253 & 1.0000 & 0.9918 & 0.9195 & 0.8553 & -0.7496 & -0.7681 & 0.9063 & 0.8757 \\
\hline $\mathbf{A c}$ & 38.065 & 25.514 & 0.9918 & 1.0000 & 0.8691 & 0.8143 & -0.7034 & -0.7274 & 0.8559 & 0.8169 \\
\hline $\mathbf{A}_{\mathbf{T}}$ & 22.440 & 22.629 & 0.9195 & 0.8691 & 1.0000 & 0.9523 & -0.8969 & -0.8940 & 0.9970 & 0.9916 \\
\hline$\varepsilon$ & 55.057 & 19.964 & 0.8553 & 0.8143 & 0.9523 & 1.0000 & -0.9820 & -0.9861 & 0.9618 & 0.9544 \\
\hline$\varepsilon^{\prime}$ & 95.703 & 4.378 & -0.7496 & -0.7034 & -0.8969 & -0.9820 & 1.0000 & 0.9971 & -0.9144 & -0.9119 \\
\hline$\varepsilon "$ & 95.975 & 3.508 & -0.7681 & -0.7274 & -0.8940 & -0.9861 & 0.9971 & 1.0000 & -0.9096 & -0.9041 \\
\hline S.C. & 10.012 & 11.778 & 0.9063 & 0.8559 & 0.9970 & 0.9618 & -0.9144 & -0.9096 & 1.0000 & 0.9963 \\
\hline $\mathbf{S}_{\mathbf{T}}$ & 3.772 & 3.911 & 0.8757 & 0.8169 & 0.9916 & 0.9544 & -0.9119 & -0.9041 & 0.9963 & 1.0000 \\
\hline
\end{tabular}

where: P - density; AC - ash content in concentrate; $\mathrm{AT}_{\mathrm{T}}$ - ash content in tailings; $\varepsilon$ - combustible matter recovery in concentrate; $\varepsilon^{\prime}$ - ash recovery in tailings; $\varepsilon$ " - sulfur recovery in tailings; $\mathrm{S}_{\mathrm{C}}$ - sulfur content in concentrate; $\mathrm{S}_{\mathrm{T}}$ - sulfur content in tailings

\subsection{Analysis of separation preciseness}

To verify effects of beneficiation the analysis of separation preciseness was conducted on the basis of partition curves and factors. On the basis of data positions in Tables 1-3 the coordinates of partition curves for jigged coal dusts tailings were calculated.

Partition curves for jigs with density as an argument of separation are asymmetric curves and can be approximated well by means of Weibull distribution function what was indicated by the investigations of other authors [7, 8]. Because of it the Weibull distribution function was used to approximate empirical partition curve. The general formula of this function is given by the equation:

$$
T(\rho)=100\left\{1-\exp \left[-\left(\frac{\rho}{\rho_{o}}\right)^{n}\right]\right\}
$$

where: $\rho o$ and $\mathrm{n}-$ are distribution function parameters. Graphs of partition curves distribution functions were presented on Figs 4-6. The continuous curve presents a model relation. The curvilinear correlation index is bigger than 0.95 . Using the approximated partition curves the separation efficiency factors were calculated and the values of these parameters were positioned on Figs 4-6. These factors were partition density $\rho r$, probable error Ep and imperfection I. The values of these parameters show that with increasing amount of additional water the values of partition preciseness factors lower, especially the values of probable error and imperfection, what means that the preciseness of jigging increases $[11,12]$.

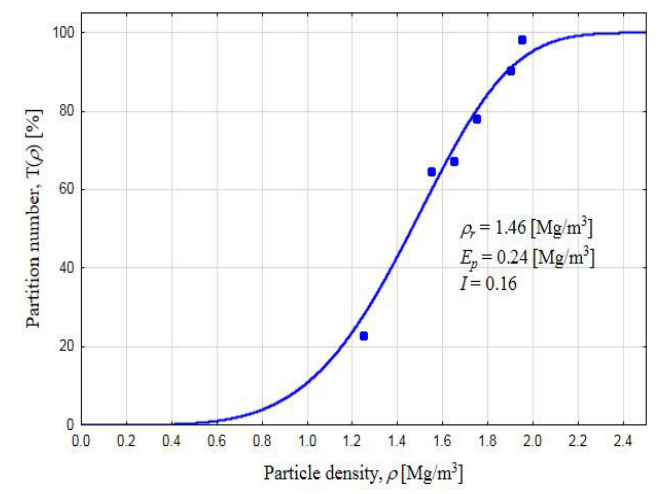

Fig. 4. Partition curve for tailings, amount of additional water $35\left[\mathrm{~m}^{3} / \mathrm{h}\right], d_{o}=1.58\left[\mathrm{Mg} / \mathrm{m}^{3}\right], n=4.75$.

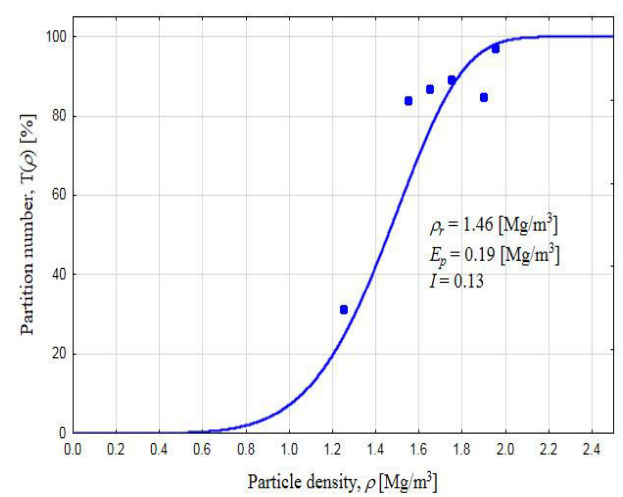

Fig. 5. Partition curve for tailings, amount of additional water $50\left[\mathrm{~m}^{3} / \mathrm{h}\right], d_{o}=1.55\left[\mathrm{Mg} / \mathrm{m}^{3}\right], n=5.94$. 


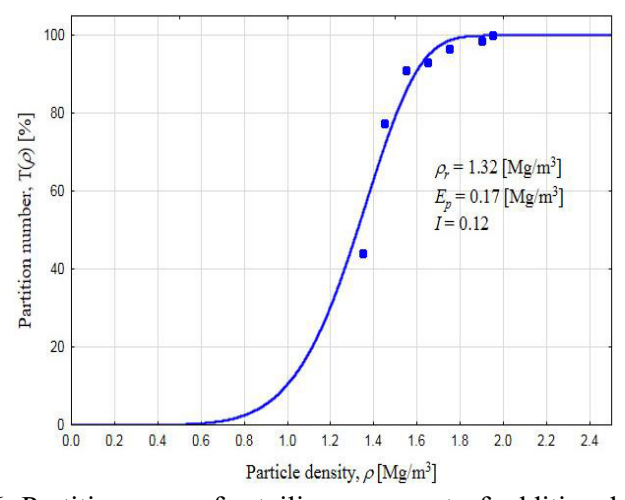

Fig. 6. Partition curve for tailings, amount of additional water $70\left[\mathrm{~m}^{3} / \mathrm{h}\right], d_{o}=1.40\left[\mathrm{Mg} / \mathrm{m}^{3}\right], n=6.58$.

\section{Summary}

The jigging process is realized in one of the main coal processing nodes and the evaluation of its effects because of achieving certain recoveries of both combustible matter in concentrate as well not useful components in tailings is a crucial part of process monitoring. This is true especially in situation of treating coal as a clean fuel and production of its qualitatively good assortments. The paper presents using of Fuerstenau approach to analyze separation effects on which basis is possible to state that the separation of combustible matter and ash in coal occurs much more efficiently than the separation of combustible matter and sulfur. This is caused most probably by the presence of organic sulfur which cannot be separated by means of gravitational separation processes [9]. Furthermore, it was stated that the hydrodynamic conditions of jig work are important during the process realization because dependably on amount of additional water delivered in purpose of ensuring sufficient particles liberation in working bed, various separation results can be achieved considering both qualitative and quantitative factors. The analysis of separation efficiency indicated that more efficient separation occurs by higher amounts of additional water. Implementation of Fuerstenau curves to evaluate coal dusts beneficiation process allows to perform analysis of process course because of its achievement of optimal recoveries of combustible matter in concentrate as well of ash and sulfur in tailings. This is very important in times when production of so-called clean coal is crucial.
This work was performed as a part of the University of Science and Technology Research Program No.11.11.100.276 project.

\section{References}

1. J. Drzymała, Podstawy mineralurgii, (Oficyna Wydawnicza Politechniki Wrocławskiej, 2001)

2. D. W. Fuerstenau, Raporty, University of California, Berkley, dane niepublikowane (1979)

3. J. Drzymała, H.A.M. Ahmed, Inter. J. Miner. Process., 76, 55-65 (2005)

4. J. Drzymała, P.B. Kowalczuk, M. Oteng-Peprah, D. Foszcz, A. Muszer, T. Henc, Minerals Engineering, 49, 17-23 (2013)

5. D. Foszcz, Zasady określania optymalnych rezultatów wzbogacania wieloskładnikowych rud miedzi, Studia, Rozprawy, Monografie, 181, (Wyd. IGSMiE PAN, Kraków, 2013)

6. D. Foszcz, T. Niedoba, T. Tumidajski, J. Pol. Miner. Eng. Soc., 16(2) (2015)

7. B. S. Gottfried, Int. J. Miner. Process., 5, 1-20 (1978)

8. A. D. Paul., Maronde C.P., Killmeyer R.P., Proc. XIII ICPC, Brisbane, II, 861-869 (1998)

9. T. Niedoba, A. Surowiak, Proceedings of the 24th International Mining Congress and Exhibition of Turkey, IMCET 2015, 717-721 (2015)

10. W. Stępiński, Wzbogacanie grawitacyjne, (ŁódźWarszawa-Kraków, Wydawnictwo PWN, 1964)

11. A. Surowiak, M. Brożek, Physicochem. Probl. Miner. Process. 52(1), 228-243 (2016)

12. A. Surowiak, Mineral Resources Management, 30(1) 105-122 (2014)

13. E. Szymkowiak, J. Drzymała, Prace Naukowe Instytutu Górnictwa Politechniki Wrocławskiej, 131, 47-56 (2010) 